\title{
Museu Paulista de Mário Neme (1960-1973)
}

The Museu Paulista of Mário Neme (1960-1973)

hitps://doi.org/10.1590/1982-02672020v28e22

\section{TATHIANNI CRISTINI DA SILVA'}

https:/ / orcid.org/0000-0002-7469-9868

Universidade Metropolitana de Santos / São Paulo, SP, Brasil

RESUMO: $\bigcirc$ presente artigo analisa a direção de Mário Neme à frente do Museu Paulista no decorrer dos anos 1960 até 1973. O intelectual assumiu o museu após o trabalho desenvolvido junto à organização da Exposição Histórica das Comemorações do IV Centenário da Cidade de São Paulo, ocorrida em 1954. Neme encontrou o museu com sérias dificuldades financeiras e de pessoal, com obras inacabadas desde 1953, o que impossibilitava o acesso do público ao espaço. A despeito das dificuldades encontradas, as ações e projetos empreendidos trouxeram mudanças significativas ao museu: desde sua abertura cotidiana ao público visitante, fortalecimento do setor de arqueologia, efetivação do curso de museologia, até sua anexação à Universidade de São Paulo, fato que o transformou paulatinamente em museu universitário. Para escrita do texto, foram analisados os relatórios anuais do museu, bem como aqueles que eram escritos pelas equipes de trabalho que compunham os quadros de pesquisadores e de funcionários da instituição. Foram realizadas, ainda, entrevistas com intelectuais e funcionários do museu. A leitura da documentação e as entrevistas concedidas permitiram perceber o Museu Paulista, durante a direção de Mário Neme, como um centro de pesquisas em desenvolvimento e importante espaço de sociabilidade dos intelectuais do período.

PALAVRAS-CHAVE: Mário Neme. Museu Paulista. Museu Universitário. Pesquisa. Arqueologia. Museologia.

\begin{abstract}
1. Bacharel e Licenciada em História pela Universidade Federal de Santa Catarina (UFSC). Mestre em Engenharia de Produção pela UFSC. Doutora em História Social pela Universidade de São Paulo (USP), bolsa Capes. Pós-doutora pela Cátedra Jaime Cortesão/FFLCH/USP. Docente na Universidade Metropolitana de Santos (UNIMES) e pesquisadora associada ao projeto de Valorização Patrimonial do Monumento Nacional Ruínas Engenho São Jorge dos Erasmos (PRCEU/USP/ BNDES) desde 2014.
\end{abstract}


ABSTRACT: This article analyzes the work of Mário Neme as Director of Paulista Museum, from 1960 to 1973. He became the Director after working with the organizing staff of the Historical Exhibition of the 40th Centenary of the City of São Paulo, in 1954. When Neme took office, the museum had serious financial and staff problems, with unfinished works since 1953. This prevented people from visiting the place. Despite the issues he faced, some actions and projects were implemented, bringing important changes to the museum: it was finally opened for visitation, the archeology section was improved, the museology course was implemented, and the museum became managed by the University of São Paulo; this turned the museum into a University Museum. Yearly reports and those prepared by the teams of researchers and staff of the institution were analyzed in the preparation of this paper. Interviews with museum staff and intellectuals were also carried out. Reading the documents and analyzing the interviews allowed realizing that, during Neme's management, Paulista Museum was a research center under development and an important social space for intellectuals during that period.

KEYWORDS: Mário Neme. Paulista Museum. University Museum. Research. Archeology. Museology. 


\section{INTRODUÇÃO}

presente artigo discute a trajetória do Museu Paulista sob a direção de Mário Neme, durante os anos 1960 até 1973. O intelectual assume a direção do museu após a instituição permanecer fechada para reformas e adaptações de 1953 até 1960. A atuação de Mário Neme foi fundamental no processo de vinculação institucional do Museu à Universidade de São Paulo, fazendo dele, assim, um museu universitário.

A pesquisa está assentada na documentação produzida anualmente pelos funcionários do museu, como os relatórios de prestação de contas de suas atividades, cartas, textos escritos para exposições, etc. Bem como na análise da bibliografia especializada, em particular dos trabalhos de Maria Margaret Lopes, Heloisa Maria Barbuy, Ulpiano Toledo Bezerra de Meneses, Ana Cláudia Fonseca Brefe, entre outros autores que discutem o papel do Museu Paulista na cultura brasileira.

Este artigo tem por objetivo estudar as ações empreendidas por Mário Neme no Museu Paulista como meio para seu fortalecimento enquanto instituição voltada para o acesso do público leigo e especializado.

Assim, o texto está organizado em seis subcapítulos que apresentam as transformações ocorridas no museu desde sua reestruturação e reabertura ao público no início dos anos 1960 até sua anexação à Universidade de São Paulo (USP), passando pela caracterização como museu universitário durante o regime militar.

\section{MÁRIO NEME E O MUSEU PAULISTA}

Mário Abdo Neme nasceu em Piracicaba, interior paulista, em 2 de maio de 1912. Seus pais Abdo Neme e Missera Miguel Neme eram de ascendência libanesa. Frequentou diversas escolas, mas não concluiu curso superior. Foi bedel na Escola Superior de Agricultura Luiz de Queiroz, e em 1931 foi aprovado como guarda-livros prático no Ginásio Municipal de Limeira. Desde muito jovem dedicou-se ao jornalismo, sob o pseudônimo de Dr. Salim, em jornais como Gazeta de Piracicaba e $O$ Momento. Aos 24 anos, mudou-se para a capital e passou a trabalhar em periódicos como Jornal da Manhã, Última Hora, O Correio de São Paulo e, por fim em $O$ Estado de S. Paulo, no qual permaneceu por toda sua vida, sendo membro da famosa "Turma de Piracicaba" que agitou e produziu o jornal durante um longo período. 
2. Enquanto esteve trabalhando na revista, publicou os seguintes artigos: NEME, Mário. Piracicaba no século XVIII. Revista do Arquivo Municipal, Documentação Histórica, São Paulo, ano IV, v. XLV, p. 131-186. mar. 1938. NEME, Mário. Um município agrícola. Aspectos sociais e econômicos da organização agrária de Piracicaba. Revista do Arquivo Municipal, Documentação Social, São Paulo, ano V, v. LVII, p. 04-96. mai. 1939. NEME, Mário. Pedro Luís. Notas para uma biografia. Revista do Arquivo Municipal, São Paulo, ano VI, v. LXIII, p. 0344. jan. 1940. NEME, Mário. Fundação de Piracicaba. Revista do Arquivo Municipal, São Paulo, ano VI, v. LXVI, p. 128-178. abr./mai. 1940. NEME, Mário. A acentuação na ortografia simplificada. Revista do Arquivo Municipal, Expansão Cultural, São Paulo, ano VII, v. LXXIII, p. 99-141. jan. 1941. NEME, Mário. Linguagem de Mário de Andrade. Separata da Revista do Arquivo, $n^{\circ}$. CVI, Departamento de Cultura de São Paulo, São Paulo/SP 1946. 10 p. A história, sua paixão desde Piracicaba, já estava presente em seus primeiros artigos.

3. PFROMM NETO (2001, p. 67-73).

4. Criado em 1893 e inaugurado em 1895, o Museu Paulista, também conhecido como Museu do Ipiranga, foi, sobretudo, um museu de História Natural em seus primeiros anos, como boa parte dos museus desse período. Sob a direção do zoólogo alemão Hermann Von Ihering (1895-1916), pesquisas na área de zoologia foram realizadas, formando uma vasta coleção, organizada e analisada, com resultados apresentados nos primeiros números da Revista do Museu Paulista. Embora a área forte do museu fosse a zoologia, outros campos do conhecimento como a História,
Sua vida como funcionário público teve início com o concurso para escriturário da Câmara municipal da capital, no entanto, com o golpe de 1937, quando a Câmara foi fechada, acabou assumindo seu posto na Divisão de Documentação Histórica e Social da Prefeitura, trabalhando na Revista do Arquivo Municipal. ${ }^{2}$ Em 1943, passou a dedicar-se também ao Boletim Bibliográfico da Biblioteca Municipal de São Paulo. ${ }^{3}$

Mário Neme tomou lugar na direção do Museu Paulista (MP) ${ }^{4}$ com o intuito de transformá-lo em um espaço pedagógico, científico e dinâmico. Com a visão da Nova Museologia ${ }^{5}$ passou a empreender diversas mudanças com a finalidade de torná-lo um museu de conceito contemporâneo sobre a História do Brasil, com ênfase no período colonial. Na mesma medida, ele assumiu a direção enquanto um intelectual modernista que acreditava na educação como mediadora de conflitos sociais. ${ }^{\circ} \mathrm{A}$ união desses dois aspectos fez do intelectual uma personagem especial, que construiv em torno de si um grande leque de possibilidades e contatos que the favoreceram intensamente durante sua gestão à frente do museu.

Quando da posse como diretor substituto do Museu Paulista, Neme recebeu um museu repleto de problemas a serem resolvidos que vinham se arrastando havia mais de uma década. Para a compreensão dessa situação, nos reportamos ao período de transição da direção do museu de Afonso d'Escragnolle Taunay’ em 1945, para Sérgio Buarque de Holanda. Desde 1917, Taunay imprimiu as feições históricas daquele espaço, mormente tratando da história de São Paulo como exemplo da História do Brasil. Um momento decisivo para isso foi a reconfiguração visual dos espaços expositivos do museu para a comemoração do primeiro centenário de Independência do Brasil, em 1922. Na ordenação do acervo exposto

\begin{abstract}
os acontecimentos estavam alinhados numa perspectiva teleológica, isto é, todo o oceano de imagens que começava no peristilo e se estendia até o salão de honra, passando pela escadaria monumental e por todas as salas anexas que contavam a saga dos paulistas na conquista do território brasileiro, tudo convergia para um único e previsível ponto de chegada prefixado: a nação brasileira fora fundada em solo paulista. A Independência brasileira aí proclamada vinha apenas confirmar esse fato. ${ }^{8}$
\end{abstract}

Assim, com a reconfiguração dos espaços expositivos do museu que enfatizavam o estado de São Paulo como a alma do país, a criação e a publicação rotineira dos Anais do Museu Paulista, ${ }^{9}$ que, editado ano a ano, tratava de questões sobre povoação, território, cultura e sociedade na História do Brasil e de São Paulo, era mais um instrumento nessa campanha. ${ }^{10}$ Também, durante a gestão de Taunay, partes significativas das coleções foram separadas do museu: primeiro, em 1927, a Seção de Botânica foi incorporada pelo Instituło 
de Defesa Agrícola e Animal. Em um segundo momento, foi criado o Departamento de Zoologia (1939), subordinado à Secretaria de Estado dos Negócios de Agricultura, Indústria e Comércio, que anexou no início dos anos 1940 a Seção de Zoologia do museu. Assim, continuaram no museu as coleções de História, Etnologia e Numismática que possibilitaram um remodelamento do museu, que gradativamente deixou de ser um Museu de História Natural para tornar-se um Museu de História. No quadro 1, vemos a organização das seções do Museu Paulista em 1893 e sua reconfiguração nos anos 1940 e 1950.

\section{Quadro 1. Esquema da organização das seções do Museu Paulista}
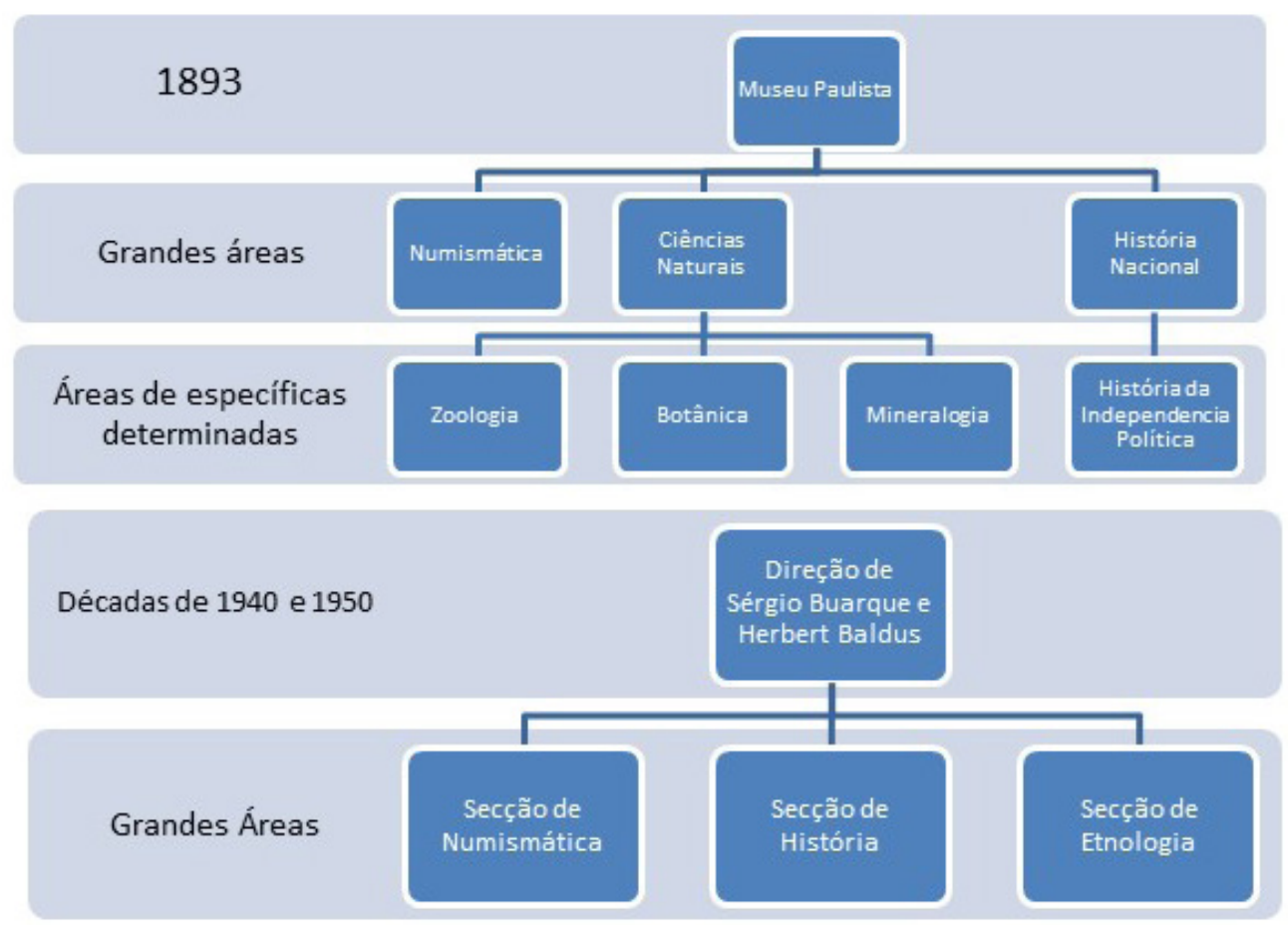

Fonte: Relatórios do Museu Paulista de 1917 até 1959.

Com a aposentadoria compulsória de Taunay em 1945, "' Sérgio Buarque de Holanda ${ }^{12}$ foi empossado diretor da instituição (1946-1956). A perspectiva do novo diretor previa um museu que estabelecesse parcerias com maior frequência com outras áreas do conhecimento que não só a história. $\bigcirc$ museu dialogou estreitamente com a etnologia na figura de Herbert Baldus, ${ }^{13}$ recém-contratado pelo novo diretor. Baldus logo se tornou o apoio forte de Sérgio no museu, e ambos fizeram da etnologia a nova estrela daquele conhecido "templo" da História. A a Etnografia e a Numismática compõem as coleções do museu desde seu início. Cf. Alves (2001); Brefe (2005); Elias (1996); Lopes (2009); Meneses (1994). No Decreto n. 249 , de 26 de julho de 1894 , as linhas de atuação do museu foram apresentadas: O caráter do Museu em geral será o de um Museu Sul-Americano, destinado ao estudo do reino animal, de sua história zoológica e da História Natural e cultural do bomem. A pesquisa e a educação também estão contempladas no decreto: Serve o Museu de meio de instrução pública e também de instrumento científico para o estudo da natureza do Brasil e do Estado de São Paulo, em particular. (REGULAMENTO DO MUSEU PAULISTA, art. $2^{\circ}, 1894: 4$ ).

5. A expressão Nova Museologia é utilizada amplamente por Mário Neme, contudo não se trata do movimento da Nova Museologia dos anos de 1970. A Nova Museologia proposta por Mário Neme compreende os museus como espaços de uso social e público para formação da população por meio de ações planejadas e que reflitam pesquisas científicas realizadas no museu. Cf. Silva (2017).

6. Cf. Candido (2008).

7. Afonso d'Escragnolle Taunay, formado em engenharia civil pela Escola Politécnica do Rio de Janeiro, foi professor na Escola Politécnica de São Paulo, no Colégio São Bento e na Universidade de São Paulo. Quando professor do São Bento ministrou aulas a Sérgio Buarque de Holanda, Rodrigo Melo Franco Andrade, entre outros intelectuais que passaram pelo colégio. Tornou-se diretor do Museu Paulista de 1917 a 1945. Possuía grande interesse pelo bandeirantismo, como vemos em seus estudos, imprimindo durante sua gestão, esta característica ao 
museu. Cf. Alves (2001); Brefe (2005); Elias (1996); Lopes (2009); Meneses (1994).

8. Brefe (2005, p. 81).

9. Criado em 1922, os Anais do Museu Paulista, publicação de destaque do museu, foi editada de forma regular até os anos 40, quando passou a ser editada de forma esporádica, voltando à regularidade nos anos 1960. Taunay publicou boa parte de seus estudos de história nesse periódico que se tornou um importante veículo para divulgação dos estudos sobre História do Brasil e São Paulo. A partir de 1993, desenvolveu-se uma nova série dos anais, agora como revista, com o subtítulo História e Cultura Material.

10. Cf. Alves (2001); Brefe (2005); Elias (1996); Lopes (2009); Meneses (1994).

11. Embora aposentado, Taunay "ia toda quarta-feira ao Museu - desde que eu [Sérgio Buarque de Holanda] estava na Direção tinha uma sala para ele lá". Holanda (2004, p 13).

12. Sérgio Buarque de Holanda encontrava-se no Rio de Janeiro, antes de assumir a direção do Museu Paulista. Seu retorno a São Paulo ocorreu após um período (1944-1946) frente à Divisão de Consulta da Biblioteca Nacional. Cf. Revista do Brasil (1987).

13. O alemão Herbert Baldus foi um importante antropólogo para os estudos da etnologia dos grupos indígenas brasileiros. Primeiro fixou-se no Rio Grande do Sul, vindo em momento posterior para São Paulo. No Museu Paulista, desenvolveu uma enormidade de pesquisas e coletas de materiais e informações, sobretudo no Centro-Oeste e Norte brasileiros, junto de seu assessor Harald Schultz. Este segundo, um teuto-brasilei-
Revista do Museu Paulista ${ }^{14}$ foi reeditada em uma Nova Série (1947), voltada, porém, para a etnologia, respeitadíssima logo em seus primeiros números.

A RMP [Revista do Museu Paulista] foi re(criada) para se tornar um espaço de publicação de trabalhos antropológicos, etnográficos e linguísticos, de produção latino-americana e internacional. Assim Sérgio Buarque de Holanda pretendia definir uma nova versão para a Revista e para os Anais, tangenciada pela demarcação de territórios e fronteiras epistemológicas no Brasil, nos anos 1940 e 1950. ${ }^{15}$

Museu Paulista entrava numa nova fase de diálogo estreito com as diferentes áreas das Ciências Humanas, fossem elas a Antropologia ou a Nova História de Sérgio Buarque de Holanda. Esse contato com aquilo que havia de novo na academia trouxe perspectivas atuais para o museu, principalmente nos seus setores de pesquisa. E transformações ocorreram velozmente: as seções estabelecidas do passado foram realinhadas e criadas novas seções que, trabalhando em conjunto, configurariam um novo perfil ao museu. Nas palavras de Sérgio Buarque de Holanda, as novas seções técnico-científicas foram "(a) de História do Brasil, especialmente de São Paulo, tendo como anexo o Museu de ltu; (b) de Etnologia; (c) de Numismática e Medalhística; (d) de Documentação Linguística". ${ }^{16}$ A aquisição de coleções para as novas seções teve início imediato, por meio de compra e coleta em pesquisas de campo, além daquelas já depositadas no museu. Nesse mesmo período, foram publicados dois volumes dos Anais do Museu Paulista, um em 1949 e outro em 1950, já a revista teve edição anual a partir de 1947, não deixando mais de ser editada. É importante salientar que a revista foi um importante espaço de sociabilidade para os intelectuais do período, assumindo um papel de troca de "possibilidades" para aqueles que a dirigiam, bem como para aqueles que queriam ver seus trabalhos publicados nela. ${ }^{17}$ No quadro 2, verifica-se a nova organização das seções do Museu Paulista em 1956.

Sérgio Buarque realizou diversas viagens enquanto era diretor da instituição, permanecendo longos períodos fora do museu. Entre 1952 e 1954, fixou-se na Itália, ministrando um curso de Estudos Brasileiros na Universidade de Roma e realizando pesquisas. Nessas ausências, Baldus assumia a direção e, assim, em 1956, com a saída de Sérgio Buarque do museu para a cátedra de História da Civilização Brasileira na Universidade de São Paulo, ele tomou seu lugar na direção. ${ }^{18} \bigcirc$ cargo de direção não seria suave para Baldus (1957 a 1959), como não o foi para Sérgio, que reclama do período em que esteve à frente da instituição: "minha letra ficou diferente de tanto assinar papel. E era um problema sempre que alguma coisa quebrava. O dinheiro chegava em junho, e quando vinha janeiro já tinha acabado. Tínhamos que pagar do próprio bolso". ${ }^{19}$ Para ambos os diretores, a função não foi fácil, no entanto, para o etnólogo a situação permaneceu bem 
mais difícil, num período de pouca verba e, por consequência, de dificuldades de trabalho e de inovações. "Os trabalhos de reforma, iniciados em março de 1953 e empreendidos em colaboração com a Secretaria de Estado dos Negócios da Viação, só em 1956 entraram em sua fase final." E, em 1959, continua o diretor: "infelizmente, porém, não foram, até agora, inteiramente terminados". ${ }^{20}$

Quadro 2. Proposta de reorganização das seções do Museu Paulista em 1956

\begin{tabular}{|c|c|c|}
\hline \multicolumn{2}{|c|}{ Década de 1950} & Proposta de mudança \\
\hline Seção & Divisão & Serviços contemplados \\
\hline \multirow{3}{*}{ História } & \multirow{6}{*}{ História } & História Paulista e História Brasileira \\
\hline & & Numismática \\
\hline & & Documentação Histórica e Coleta de Material \\
\hline \multirow{3}{*}{ Numismática } & & Conservação \\
\hline & & $\begin{array}{l}\text { Museu Republicano Convenção de Itu, com } \\
\text { dedicação especial a cultura luso-brasileira }\end{array}$ \\
\hline & & Anais do Museu Paulista. \\
\hline \multirow{6}{*}{ Etnologia } & \multirow{6}{*}{ Antropologia } & Etnologia e Arqueologia \\
\hline & & Documentação Linguística \\
\hline & & Antropologia Física e Folclore \\
\hline & & Coleta de Material \\
\hline & & $\begin{array}{l}\text { Procurará elucidar os problemas do índio e do } \\
\text { caboclo de todo o nosso continente }\end{array}$ \\
\hline & & Revista do Museu Paulista \\
\hline
\end{tabular}

Fonte: Relatórios de Atividades do Museu Paulista de 1954, 1955 e 1959.

Assim, de 1895 a 1959, o Museu Paulista havia passado por mudanças extremamente significativas que resultaram em um espaço de múltiplas possibilidades desagregadas, que precisavam ser trabalhadas para uma nova estruturação do espaço e de seus objetivos. Embora o número de diretores tenha permanecido pequeno, devido ao longo período em que cada um deles passou pela instituição, suas personalidades e projetos permaneceram enraizados. Hermann von thering imprimiu a pesquisa e o caráter de interesse internacional ao museu; Afonso d'Escragnolle Taunay trouxe a História de São Paulo como exemplo de História do Brasil para o centro da produção; Sérgio Buarque de ro de Porto Alegre, que foi aluno de Baldus, na Escola Livre de Sociologia e Política (ELPS). Cf. Françoso (2005).

14. A Revista do Museu Paulista, com primeiro número em 1895 era voltada para História Natural. Von Ihering publicou ali a maioria de seus estudos acerca das coleções do museu, contribuindo para a grande notoriedade da publicação. Em 1938, a Revista do Museu Paulista deixou de ser publicada.

15. Valente '(2009, p. 139).

16. Cf. Baldus (1955).

17. Cf. Sirinelli (2003).

18. Cf. Baldus (1955; 1960a).

19. Holanda (2004, p. 12).

20. Baldus (1960b, p. 1). 
21. Hayashi (2001, p. 137)

22. O Instituto de Pré-História e Etnologia de 1959 , vinculado à Casa Civil do estado de São Paulo, desenvolveu suas atividades com sucesso, e conseguiu grande visibilidade com seu trabalho de pesquisa e proteção na área. Em 17 de dezembro de 1962, com o decreto $\mathrm{n}^{\circ} 41.222$, foi criado na Universidade de São Paulo o Instituto de Pré-história (IPH), com Paulo Duarte como diretor. Ibid., p. 137

23. Grifo da autora.

24. Ibid., p. 137.

25. Ibid., p. 137-138. Grifos da autora.
Holanda apresentou a etnologia como um grande potencial de pesquisa e acervo; Herbert Baldus estreitou os laços do museu com a antropologia, na presença cada vez mais forte da etnologia, da linguística e da arqueologia, fortalecendo os laços com o estrangeiro. $\bigcirc$ ano de 1960 apresentou-se como o momento para a união de todo esse potencial reunido na instituição ser ofertado ao público e utilizado pela comunidade acadêmica e civil de forma mais viva.

\section{MÁRIO NEME, DIRETOR DO MUSEU PAULISTA}

O cargo de diretor do Museu Paulista surgiu para Mário Neme por intermédio de Paulo Duarte, diretor em exercício no museu em 1959/60. Segundo Marli Guimarães Hayashi (2001), "convidado por Jânio Quadros em dezembro de 1958, o jornalista [Paulo Duarte] pretendia transformar o órgão em um moderno instituto de cultura, sendo subdividido em dois museus o de História e o de Etnologia e Pré-História". ${ }^{21}$ Essa ideia, pelo que já foi apresentado, não era uma grande novidade, mas para esse intelectual a separação dos acervos surgia como uma interessante possibilidade para se pensar o fortalecimento do recém-criado Instituto de Pré-História e Etnologia22 (1959). Paulo Duarte vinha há algumas décadas lutando pela criação do instituto, mas, devido às inúmeras disputas e inimizades envolvidas, o projeto demorou demasiado a sair do papel. Marli Guimarães Hayashi nos explica que "Paulo Duarte aceitou tomar posse do cargo, mas sem assumir o exercício porque queria primeiro garantias de que receberia os recursos necessários às mudanças." E "ele não aceitava ser diretor de um 'depósito', ${ }^{23}$ como supostamente seria o Museu Paulista". ${ }^{24}$ Com essa exigência, Duarte acaba por não assumir efetivamente o Museu Paulista. Ele deixou a direção da instituição para dedicar-se a um cargo no Gabinete dos Negócios da Educação, em 1960.

No entanto, Paulo Duarte afirma indicar seu substituto. Ainda segundo Marli Guimarães Hayashi, ele decide ajudar o amigo Mário Neme para sucedê-lo, mas em sua observação, este era um ilustre desconhecido como historiador, fato bastante contestável, segundo pesquisas realizadas.

Essa condição de Neme preocupou o secretário da Educação porque havia funcionários do Estado candidatos ao posto, "que embora maus, pelo menos eram tidos como historiadores". A fim de desfazer o argumento e ajudar o amigo, Paulo Duarte publicou por sua editora, a Anhembi, o livro de Mário Neme, Notas de Revisão da História de São Paulo. Para o jornalista, o lançamento da obra "o consagrou como historiador" e assim ele pode ocupar a função. ${ }^{25}$ 
Em 9 de fevereiro de 1960, Neme tornou-se diretor substituto do museu com a tarefa de reavivá-lo, pondo em prática antigos objetivos de torná-lo um dos mais importantes espaços de cultura da cidade. A tarefa não seria fácil, pois o museu se encontrava em meio a sérios problemas de verba e pessoal para as atividades cotidianas, como citado anteriormente. Contudo, o intelectual já possuía uma vasta experiência com a administração pública e as dificuldades de verba e pessoal em instituições.

Contradizendo Paulo Duarte, o convite para a direção do museu feito a Neme não foi por acaso, pois há muito ele vinha desenvolvendo atividades ligadas ao setor cultural, tornando-se notório pelo bom desempenho frente a outros desafios, como ele mesmo comenta:

[...] A nossa experiência profissional provem do trabalho desenvolvido na montagem e funcionamento da Exposição de História de São Paulo no quadro da História do Brasil, comemorativa do IV Centenário da Cidade de São Paulo (1953-1956), na instituição da Casa do Bandeirante, em São Paulo (1953), na remontagem e funcionamento da Exposição de Artes e Técnicas Populares (1956-57), na Junta Coordenadora dos Museus Municipais, da Secretaria de Educação e Cultura da Municipalidade de São Paulo (1958-59) [...] $]^{26}$

Em sua descrição, o autor dá notícia de sua formação para autorizá-lo a falar acerca da formação de acervos, bem como de sua conservação, restauro e a dirigir um museu. Isso é fundamental, pois devemos lembrar que ele não possuía formação universitária, o que o autorizou em suas atividades foi sua trajetória intelectual construída de forma empírica, iniciada no Departamento de Cultura, nos anos 1930.

Toda trajetória social deve ser compreendida como uma maneira singular de percorrer o espaço social, onde se exprimem as disposições do habitus; cada deslocamento para uma nova posição, enquanto implica a exclusão de um conjunto mais ou menos vasto de posições substituíveis e, com isso, um fechamento irreversível do leque dos possíveis inicialmente compatíveis, marca uma etapa de envelhecimento social que se poderia medir pelo número dessas alternativas decisivas, bifurcações da árvore com incontáveis galhos mortos que representa a história de uma vida. ${ }^{27}$

envelhecimento social de Mário Neme ocorreu por seu deslocamento em diferentes instituições e a criação de redes de sociabilidades possíveis, desenvolvidas por trinta anos que the habilitaram para a direção do Museu Paulista, como um homem de notório saber, ou um intelectual reconhecido por seus pares. Convocando Sirinelli para a discussão, talvez Neme possa ser inserido em um grupo de "intelectuais intermediários, aqueles de menor notoriedade, [porém] exercendo uma influência cultural e mesmo às vezes política". ${ }^{28}$ Ele gravitava em meio aos grandes 
29. Para mais informações sobre o Departamento de Cultura, cf. Raffaini (2001); Duarte (1976).

30. Segundo Lilia M. Schwarcz era comum se ouvir nas reuniões do IHGSP, desde sua fundação, a frase "A História de São Paulo é a História do Brasil". Frase que seria uma provocação aos cariocas que se autodenominavam um Instituto Brasileiro. Schwarcz (2011. p. 126-127). A presença dos institutos seria mais um dos elementos de disputa entre os intelectuais dos dois estados.

31. O Museu Paulista, também é conhecido popularmente como Museu do Ipiranga, referência à região em que está instalado

32. Duarte (1976, p. 248)

33. Os primeiros MHP foram designados à memória dos quatro primeiros presidentes republicanos civis e paulistas da primeira República (1890-1930): MHP Prudente de Morais (1894-1898), em Piracicaba; MHP Campos Salles (1898-1902), em Campinas; MHP Rodrigues Alves (1902-1906), em Guaratinguetá; e MHP Washington Luís (1926-1930), em Batatais. Por serem os primeiros e por constituírem eles próprios uma matriz da rede, deve ser destacada certa singularidade no que se refere ao tratamento que lhes foi dado. Misan (2008, p. 5).

34. Ibid., p. 5. intelectuais do período, fato que como perceberemos no decorrer deste trabalho o auxiliou e influenciou em suas conquistas.

Suas primeiras ações durante a gestão do museu demonstram um pouco da influência desses contatos. A proposta de modernização do Museu Paulista incluía a transformação das seções de História e Etnografia em duas divisões que, posteriormente, seriam transformadas em dois institutos autônomos ao Museu Paulista e ligados à USP. Como vimos pelo quadro 2, a proposta de revisão do organograma da instituição já era proposta e desejada desde meados dos anos 1940 por sua nova direção. A nova proposta surgiu junto à Comissão de Estudos dos Institutos Universitários e Anexos presidida por Paulo Duarte em que se discutiam a criação de diversos outros institutos dentro da universidade. Paulo Duarte estabeleceu desde sua passagem pela criação (1935) do Departamento de Cultura ${ }^{29}$ de São Paulo uma ligação próxima com o Museu Paulista. Quando informado sobre arquivos de documentos históricos que necessitassem de cuidados e guarda, ele solicitava o encaminhamento ao museu. Em outros momentos, Paulo Duarte denuncia o péssimo estado de conservação da documentação do Arquivo do Estado de São Paulo e observava que existem coleções ameaçadas "de destruição total, muitos pacotes de documentos preciosos apodreceram irremediavelmente". Afirmava por outro lado que os que ainda estavam em condições de tratamento precisavam ter sua salvaguarda garantida, e que para tanto passariam pelo Instituto Histórico e Geográfico de São Paulo ${ }^{30}$ para organização, restauro e publicação e, "feito isso, os documentos seriam recolhidos ao Museu do Ipiranga, ${ }^{31}$ encarregado da sua guarda e conservação". ${ }^{32}$ Diga-se a propósito que este intelectual colaborou com a identificação do museu como um espaço especial/ideal para guarda da memória de São Paulo/Brasil, enquanto um estado republicano, diferentemente do estado do Rio de Janeiro, que permaneceria com a carga negativa de sede do Império. Simona Misan faz uma interessante observação sobre a atuação diferenciada do Instituto Histórico e Geográfico de São Paulo e a criação dos museus históricos do estado, baseados nas figuras presidenciais republicanas.

Ao criar, em 1956, os MHP [Museus Históricos e Pedagógicos] dedicados à memória dos quatro presidentes ${ }^{33}$ republicanos paulistas, Sólon Borges dos Reis, então há seis anos membro do IHGSP, parecia cumprir dupla missão: não somente procurava afirmar a participação do estado de São Paulo no imaginário republicano (sobretudo no da oligarquia paulista), bem como buscava reforçar a identidade do IHGSP, como guardião e leal depositário desta memória. Ao tentar perpetuar a participação política dos presidentes republicanos paulistas, o IHGSP procurava não somente fixar os seus símbolos no imaginário republicano, como reforçava seu papel, contrapondo-se ao Instituto Histórico e Geográfico Brasileiro (IHGB), no Rio de Janeiro [...] $]^{34}$ 
A disputa entre Rio de Janeiro e São Paulo no contexto de nosso estudo é fundamental, pois é um dos elementos definidores das tomadas de posição e direcionamento de políticas públicas nos setores culturais e sociais. ${ }^{35}$ São Paulo era construída/imaginada como a cidade/estado ${ }^{36}$ do futuro, o centro do progresso para o Brasil, então, o exemplo da República, por consequência, o Rio de Janeiro era o passado, o Império, ou seja, tudo aquilo que deveria ser superado em prol de um futuro ascendente. Segundo Maria Arminda Arruda, quando em meados do século XX São Paulo é alçada "à condição de metrópole, sua condição de cidade com ar cosmopolita e as mudanças econômicas e sociais que ocorriam, trouxeram formas novas de sociabilidade, traduzidas nas mudanças relativas à cultura". ${ }^{37}$

\begin{abstract}
O experimentalismo vanguardista adquiriv em São Paulo inequívoca ambientação, uma vez que o concretismo na poesia teve na cidade a sua expressão mais acabada. $\bigcirc$ quadro não se fecha sem que se considere a institucionalização da vida universitária que acabou por alterar o estilo de reflexão, assim como a constituição das organizações de cultura, os museus, os teatros, o cinema, conferiram lastro material à divulgação das obras produzidas no exterior, adensando o processo de trocas culturais. ${ }^{38}$
\end{abstract}

Com estas mudanças e novos museus, um projeto antigo do Museu Paulista teve destaque. Iniciou-se a criação de um curso de Museologia, a ser ministrado nas dependências do museu. Embora pretendido por outras gestões, ele nunca foi completamente efetivado. Na gestão de Mário Neme ele se tornaria real, inclusive com verbas federais para o curso já em andamento garantidas pela direção do DPHAN. ${ }^{39}$ Essas medidas provinham não só de Neme, mas também de um grupo no qual ele estava inserido e que pretendia a modernização do museu e da USP. Entre os interessados figuravam Paulo Duarte, Sérgio Buarque de Holanda, Rodrigo Melo Franco Andrade, intelectuais que se lançaram à frente de projetos de mudanças significativas para a educação e a cultura em São Paulo e no Brasil.

curso que tinha por público-alvo "alunos e licenciados das diversas cadeiras da Faculdade de Filosofia, Ciências e Letras" foi caracterizado como "extensão universitária, visando capacitar o aluno a resolver problemas de planificação, catalogação, conservação, restauração, exposição, etc. do material correspondente a cada gênero do museu" . 40 A verba para o curso veio da Diretoria do Patrimônio Histórico e Artístico Nacional, dirigida por Rodrigo Melo Franco Andrade, e da Organização Internacional de Museus/Unesco com representação brasileira, durante muito tempo, de Sérgio Buarque de Holanda. A verba foi solicitada pessoalmente por Paulo Duarte, enquanto era diretor do museu, e as negociações seguiram-se com Mário Neme. ${ }^{41}$ É interessante notar as relações pessoais que permeavam essas quatro figuras que
35. Cf. Sevcenko (2009); Arruda (2001); Barbuy (2006).

36. Misan (2008, p. 6) ressalta também as disputas internas entre as oligarquias, que também representam uma forte tensão nas tomadas de decisões sobre o tipo de patrimônio cultural a ser alicerçado. A criação dos MHP parecia, então, atender antigas reivindicações de representatividade de São Paulo no imaginário republicano. Outra particularidade a ser destacada, com relação a este primeiro conjunto de MHPs, é o fato de, além de disputarem seu quinhão no processo de construção da memória na República, os museus paulistas parecerem ainda, representar certas disputas entre antigos poderes das oligarquias regionais do estado em algumas cidades como Itu, Piracicaba, Campinas, Guaratinguetá e Batatais.

37. Arruda (2001, p. 20)

38. Ibid., p. 21

39. Em 1946, o SPHAN (Serviço do Patrimônio Histórico e Artístico Nacional) fundado em 1937, foi transformado em Departamento do Patrimônio Histórico e Artístico Nacional/DPHAN. Sofreu alteração novamente em 1970, tornando-se Instituto do Patrimônio Histórico Artístico Nacional/IPHAN.

40. Neme (1961[2], p. 8).

41. Cf. Neme (1961[2]; 1963). 
42. Sirinelli (2003, p. 248)

43. Neme (1963, p. 5). eram amigos pessoais de longa data. Segundo Sirinelli, "o mundo intelectual constitui, ao menos para seu núcleo central, um 'pequeno mundo estreito', onde os laços se atam, por exemplo, em torno da redação de uma revista", 42 em nosso caso, em torno de um museu. Os laços de sociabilidade estabelecidos por Neme foram fundamentais, como neste caso, para sua atuação.

Em 1962, Neme deu notícias do curso de museologia que passou a ter lugar nas dependências no museu. $\bigcirc$ curso tinha "duas séries de aulas, uma para Museu de História, outra para Museu de Zoologia." Sendo que, "aos professores [do curso] foi recomendado que imprimissem caráter prático ao ensino, com objetivo de transmitir os conhecimentos técnicos de organização e funcionamento de museus. "43 Aproximadamente 50 alunos constituíram a primeira turma de museólogos formados pelo Museu Paulista. Abaixo, no quadro 3, a grade de disciplinas dos cursos.

Quadro 3. Grade curricular dos cursos de Museologia para Museu Histórico e Museu de Zoologia

\begin{tabular}{|c|c|}
\hline Museologia para Museu Histórico & Museologia para Museu de Zoologia \\
\hline I. Organização e funcionamento & $\begin{array}{l}\text { a. Objetivos: científico, educativo, popular } \\
\text { b. Estrutura e funcionamento }\end{array}$ \\
\hline $\begin{array}{l}\text { I. Classificação e catalogação } \\
\text { Cerâmica/ mobiliário / arte sacra }\end{array}$ & $\begin{array}{l}\text { c. Coleções de vertebrados (Pesquisa) } \\
\text { C. 1. Mamíferos e aves: coleções secas } \\
\text { C. 1.1. Curadoria, conservação, arrumação, rotulagem, } \\
\text { catalogação } \\
\text { C. 1.2. Coleta } \\
\text { C. 1.3. Preparo } \\
\text { C.2. Répteis, anfíbios e peixes: coleções em via úmida } \\
\text { C.2.1. Curadoria, conservação, arrumação, rotulagem, } \\
\text { catalogação } \\
\text { C.2.2. Coleta } \\
\text { C.2.3. Preparo }\end{array}$ \\
\hline
\end{tabular}




\begin{tabular}{|c|c|}
\hline $\begin{array}{l}\text { III. Conservação e restauração } \\
\text { Obras de arte / pintura / escultura } \\
\text { em madeira / gesso / documentos }\end{array}$ & $\begin{array}{l}\text { d. Coleções de invertebrados (Pesquisa) } \\
\text { Dom 1. Insetos (coleções secas) } \\
\text { D. 1.1. Curadoria } \\
\text { D. 1.2. Coleta } \\
\text { D. 1.3. Preparo } \\
\text { Dom2. Coleções em via úmida } \\
\text { D.2.1. Curadoria } \\
\text { D.2.2. Coleta: terrestres, água doce, marinhos } \\
\text { D.2.3. Preparo }\end{array}$ \\
\hline $\begin{array}{l}\text { IV. Utilização cultural de material de } \\
\text { museu } \\
\text { Arquivismo / pesquisas e estudos / } \\
\text { exposições didáticas e públicas / } \\
\text { divulgação por: imprensa, fotogra- } \\
\text { fia, cinema, televisão }\end{array}$ & $\begin{array}{l}\text { e. Serviço de documentação } \\
\text { E. 1. Biblioteca } \\
\text { E. 1.1. Constituição } \\
\text { E. 1.2. Parte referência } \\
\text { E. 1.3. Uso } \\
\text { E. 2. Desenho } \\
\text { E. 3. Fotografia }\end{array}$ \\
\hline $\begin{array}{l}\text { V. Paleografia prática e tratamento } \\
\text { de documentos históricos }\end{array}$ & $\begin{array}{l}\text { e. Publicações } \\
\text { F.1. Preparo de originais } \\
\text { F.2. Parte gráfica } \\
\text { F.3. Permuta } \\
\text { f. Exposição pública } \\
\text { G. 1. Planejamento } \\
\text { G.2. Taxidermia } \\
\text { G.3. Ambientes naturais } \\
\text { G.4. Rotulagem } \\
\text { h. Viveiros }\end{array}$ \\
\hline
\end{tabular}

Fonte: Dados retirados do Relatório de Atividades do Museu Paulista de 1962, p. 5-6. 
44. O Decreto $\mathrm{n}^{\circ} 21.129,7$ mar. 1932, cria o Curso de Museus no MHN. Cf. Siqueira (2009).

45. Gustavo Barroso dirigiu o MHN de sua criação em 1922 até 1959 , quando veio a falecer. Tornou o museu num importante espaço para a história da nação, portanto de encontro com as políticas Varguistas de então.Cf. Faria (2017); Magalhães (2009).

46. A primeira proposta curricular datada de 1932/33, contava em seu primeiro ano com as disciplinas de Arqueologia Aplicada ao Brasil, História da Arte (especificamente do Brasil), História Política e Administrativa do Brasil (ênfase no período colonial) e Numismática. No seu segundo ano as matérias eram: História Política e Administrativa do Brasil (até a atualidade), Numismática (brasileira) e Sigilografia, e por fim a disciplina direcionada Técnica de Museus com Epigrafia e Cronologia. Em 1935 um novo currículo foi implantado, com algumas poucas mudanças, como é possível perceber, mas que convergem com um novo entendimento acerca da história nacional como uma grande civilização/nação. Surgiu a disciplina História da Civilização Brasileira (período colonial) no primeiro ano, e com mesmo nome no segundo ano abarcando o período até a atualidade; História da Arte Brasileira, Arqueologia Brasileira e Numismática (parte geral) para o primeiro ano; para o ano seguinte, havia ainda, Numismática (parte brasileira) e Sigilografia, além de Técnica de Museus, Epigrafia e Cronologia. Siqueira (2009, p. 170-171).

47. Reforma curricular de 1966/1970. $1^{\circ}$ ano $-1^{\circ}$ semestre: Artes Menores, Estética, Comunicações Muse-
Com as grades apresentadas, houve a formação de profissionais para diversos museus de São Paulo e do Brasil. O país vivia um tempo de florescimento de museus em vários estados, por meio de incentivo federal através do DPHAN. Funcionários do Museu Paulista e do Museu de Zoologia também fizeram o curso, que tinha em sua proposta inicial dar formação ao seu quadro de funcionários. As aulas foram ministradas no decorrer de um ano. $\bigcirc$ curso foi marcadamente técnico, focado nas questões práticas e cotidianas de um museu dentro de suas especialidades, como se observa na grade curricular didática que passa da maneira como funciona um museu até a apresentação de uma exposição.

É importante lembrar que no Brasil já existia outro curso para museus, ${ }^{44}$ bastante antigo, sediado no Museu Histórico Nacional (MHN), no Rio de Janeiro, datado de 1932, tido como o primeiro das Américas. No entanto, embora tenha passado por diversas reformas, esse curso era muito mais amplo e versava também sobre conhecimentos gerais acerca da história, da arte, da numismática, etc., pretendendo também uma análise de conteúdo do material apresentado. Organizado em dois anos, - Curso de Museus, como foi chamado, pretendia formar sobremaneira funcionários para o recém-inaugurado $M H N$, de 2 de agosto de 1922, fruto das comemorações do centenário da independência do país, e do trabalho de Gustavo Barroso. ${ }^{45} \mathrm{Com}$ apenas uma disciplina técnica, como podemos ver abaixo na terceira proposta curricular ${ }^{46}$ que vigou de 1944 a 1965, há uma enorme carência de conteúdos que viabilizem o cotidiano de um museu, como conservação e restauro de objetos, técnicas de exposição, salvaguarda de obras, entre tantos outros itens essenciais à formação de pessoal para trabalho direto com o acervo. Em 1966 aconteceu uma nova reformulação da grade de disciplinas, ${ }^{47}$ e então o curso tornou-se técnico, abrangendo uma série de disciplinas como comunicações museológicas, museologia teórica, etc., até então negligenciadas. Uma mudança substancial nesse curso foi a criação do seu terceiro ano, então direcionado para uma das seguintes áreas: museus históricos, artísticos ou científicos. ${ }^{48}$ Essa transformação foi reflexo do crescente número desses museus pelo país, influenciado em grande parte pelo Serviço do Patrimônio Histórico e Artístico Nacional (SPHAN) e pela crescente necessidade de profissionalização desses conhecimentos. Infelizmente, o curso não fugiu da reforma educacional promovida pelo regime militar e passou a ter uma disciplina completamente alheia a suas necessidades, constante no decorrer dos dois anos de aulas, o curso de Moral e Cívica, sinal dos tempos agitados e de total intervenção militar que estavam por vir. $\bigcirc$ Curso de Museus permaneceu vinculado ao MHN até 1976, quando se tornou curso universitário, primeiro sob as Escolas Federais Isoladas do Estado do Rio de Janeiro (Fefieri), depois transformadas em 1979 em Universidade do Rio de Janeiro (UNI-RIO), passando a ser chamado de Curso de Museologia. ${ }^{49}$ 
Desta maneira, o curso de museologia oferecido no Museu Paulista, no início dos anos 1960, dialoga pouco com seu congênere fluminense. Pelo quadro de disciplinas oferecidas percebe-se que o curso do Museu Paulista se desenvolveu voltado para a técnica, enquanto o curso do Museu Nacional possuía características mais analíticas. Estava na proposta do curso a formação de corpo técnico para os museus de São Paulo, embora tivesse duas de suas funcionárias, a senhora Marcelina Alves Brandão e a senhora Márcia Barreto, formadas naquela escola. Ele apresenta uma relação mais estreita com o curso de mesmo nome oferecido por João Couto, 50 junto do Museu Nacional de Arte Antiga, de Portugal. A partir dos anos 1950, este assumiu a cadeira de Museologia no curso para Conservadores dos Museus, Palácios e Monumentos Nacionais, organizado pelo Museu Nacional de Arte Antiga (MNAA), referência a partir do seu diretor neste assunto. A ementa é basicamente técnica e pretende, por meio de exemplos com imagens e visitas técnicas, explicar o cotidiano de um museu e suas necessidades. Com aproximadamente 26 lições, o professor perpassa desde a criação de um museu com sua instalação física até a escolha e doação do acervo, chegando ao momento da pesquisa das peças por profissionais de cada área do conhecimento. Esse curso possui um fino diálogo com o oferecido no MP, no qual ambos pretendem a formação de pessoal que conheça efetivamente a realidade e o cotidiano de museus. Esses cursos têm por preocupação a criação de funcionários que possam atuar diretamente com o acervo e com o público, estabelecendo diálogo com o mesmo nível de seus visitantes, diferentemente dos especialistas que, como será observado, não conseguirão dialogar com o público desses lugares.

Quando dispostas lado a lado as duas propostas, percebe-se a similaridade das ideias, ambas iniciam com a noção de museu, apresentam o que contempla esse espaço, suas necessidades e diversidades. Essa tendência no cuidado com o patrimônio, da salvaguarda dos objetos em museus e da criação de aparelhamentos para estes se relaciona também com as grandes guerras e outros inúmeros distúrbios sociais que ocorreram no início do século XX e que puseram em risco os referenciais de cultura dos cinco continentes.

\section{OS ESCOLARES}

Outro fator de contribuição para transformações no cotidiano do museu ocorreu com a institucionalização de visitas monitoradas para as escolas. As preocupações com um melhor atendimento e o crescimento dos alunos no ambiente reforçaram o ológicas, Museologia Teórica, História da Civilização, Ciências Auxiliares da História - Noções Gerais, Antropologia, Cosmografia e Cartografia, Biogeografia, Geografia Física. $2^{\circ}$ semestre: História da Arte, Estética, Comunicações Museológicas, Museologia Teórica, História da Civilização, Numismática, Antropologia, História Luso-brasileira, Moral e Cívica. $2^{\circ}$ ano $-1^{\circ}$ semestre: História da Arte, História Luso-brasileira, História da Arte Brasileira, Artes Menores, Vidros, Cristais e Vitrais, Heráldica e Genealogia, Numismática, História Geral. $2^{\circ}$ semestre: Armaria, Cerâmica, Porcelanas e Mosaicos, Numismática, Moral e Cívica, História Luso-brasileira, História da Arte, História da Arte Brasileira. O terceiro ano estava dividido em 03 Seções distintas: Seção de Museus Históricos, Seção de Museus Artísticos e Seção de Museus Científicos. Desta maneira era possível oferecer uma formação diferenciada e de acordo com as necessidades específicas de cada órgão, denotando a profissionalização da área. Siqueira (2009, p. 176-178)

48. A Seção de Museus Históricos contava com as seguintes disciplinas no primeiro e segundo semestres: História Militar e Naval do Brasil, Arqueologia (Folclore e Arte Popular no Brasil, Geologia, Arqueologia Geral e da Pré-história e Arqueologia do Brasil), Sigilografia e Filatelia, Técnica de Museus ( Joalheria e Prataria, Indumentária, Rendas e Bordados, Mobiliário, Museografia, Tapeçarias e Bandeiras, Navios e Aeronaves, Viaturas terrestres), Metodologia de Pesquisas Museológicas e Moral e Cívica.

49. Cf. Siqueira (2009).

50. Nascido João Rodrigues da Silva Couto (1892-1968) em Coimbra, realizou sua 
formação na Universidade de sua terra natal. Primeiramente como bacharel em Direito (1913) e posteriormente como licenciado em Ciências Histórico-Geográficas (1914-1915). Logo se tornou professor do Liceu e conservador do Museu em sua cidade. Em 1928, já em Lisboa, tornou-se conservador-adjunto do Museu Nacional de Arte Antiga. Em 1938 é elevado ao cargo de diretor do mesmo museu, função exercida até 1964. Costa (2012, p.137).

51. Leite (1960, p. 5).

52. Ibid., p. 6 aspecto pedagógico que o museu adquiriu ao longo de sua trajetória. A presença de crianças e adolescentes circulando pelas exposições exigiu dos funcionários uma didática em suas explicações, mas, antes de qualquer outra coisa, a preocupação com uma museografia em que as peças expostas passaram a ser explicativas e um conjunto de ações teve que ser pensado para garantir a atenção e o interesse dos alunos pelo acervo. Já em seu primeiro relatório para Neme, o historiógrafo e chefe da seção de História Francisco Rodrigues Leite comenta acerca dos visitantes escolares ao museu:

De maneira geral, a não ser nas três últimas turmas do item a) [Escola de Artes Gráficas do SENAl (50 alunos); Instituto Nelson Fernandes (29 alunos); Ginásio e Liceu Eduardo Prado (150 alunos)], dispersivos, desinteressados e até pouco disciplinados, notou o Conservador nesses visitantes atitude receptiva e disposição de aproveitamento. Interesse pouco fora do comum foi demonstrado pelos representantes do Colégio "Estella Maris", talvez por ser um grupo pequeno [oito alunos] e homogêneo. Mas em regra os que vieram de outras unidades do país estavam compenetrados de que estavam percorrendo uma exposição de que se podiam beneficiar. Situação inteiramente diferente das crianças de cursos primários. Sem exceção, era visível neles a falta de participação, como se nada estivesse no plano de sua mentalidade. ${ }^{51}$

No plano de divisão de atividades proposto pelo diretor, um funcionário da seção de História ficaria responsável pelo monitoramento das visitas às salas de exposição histórica, e outro funcionário da seção de Etnologia seria responsável pela visitação às exposiç̃ões relacionadas à antropologia. A divisão de tarefas devia-se à ausência de funcionários para todas as atividades do museu. Embora a colaboração dos funcionários, não havia por parte deles interesse em manter-se à frente da atividade por muito tempo, e logo, sugestões foram feitas:

Embora provisória essa atividade do Conservador, pois, quando o Museu estiver suficientemente aparelhado, certamente contará com monitores especializados para a função, mesmo assim indaga D. Maria Barreto se por ora o acompanhamento de nível primário não poderia ser uma servente com algum treino para isso. Estando eu de acordo com a sugestão, submeto-a a consideração de V.S. ${ }^{52}$

A tarefa de manter as visitas escolares com o monitoramento se tornou um grande problema a ser resolvido, permanecendo por muito tempo devido à constante falta de pessoal para as atividades básicas do museu. acompanhamento de crianças às exposições com um trabalho de guiamento foi um processo bastante delicado e longo para conscientização de todo o núcleo que compunha as atividades da instituição. Segundo Edgar Süssekind de Mendonça, em texto clássico de 1946, havia um apelo desde os anos 1936, com o Congresso da Museums Association, em Leeds, para que "fosse o museu considerado sócio solidário na tarefa educativa, e não apenas - honra de que 
ele declinava - sócio benfeitor". ${ }^{53}$ Percebemos um movimento de inserção dos museus nas escolas, com projetos claros e objetivos pedagógicos a cumprir.

Edgar Süssekind de Mendonça elenca critérios que os museus devem seguir para estabelecer um contato frutífero com as escolas: a) "Comunicabilidade", utilização de diferentes artifícios visuais para interação "entre o material exposto e o público [...] tornando acessível à mentalidade dos observadores comuns o que outrora se reservava para o uso exclusivo dos especialistas"; b) "Ampliação da coleta de exemplares, transitando do raro e maravilhoso para o comum e familiar", favorecendo uma aproximação com a cultura local/regional; c) "Unificação do material pertencente a um mesmo conjunto natural ou social", a apresentação didática dos materiais pertencentes à instituição seja por meio de "quadros sinóticos, mapas, gráficos"; d) "Ecologia dominando taxonomia", uma introdução do que será apresentado durante uma seção da exposição com mostruários explicativos; e) "Renovação dos temas de visitas escolares", diferentes questionamentos acerca das possibilidades da coleção; f) "Psicopedagogia aplicada aos museus", o contato diferenciado com cada público e suas diferentes necessidades e anseios. ${ }^{54}$

As diretrizes traçadas por este autor são em grande medida as propostas por Mário Neme para o museu. Em relatório de 1960, o diretor define as metas para aquele ano e os próximos, quanto às exposições:

Tendo tido oportunidade de verificar o nenhum aproveitamento das visitas de escolares ao Museu, por desconhecerem os professores acompanhantes, em geral, a significação de peças expostas ou de fatos históricos com elas relacionados, resolvemos instituir um serviço de monitores para esses grupos de estudantes, indicando-thes de preferência os dias em que o Museu não estará franqueado ao público..$^{55}$

A importância de um público que entendesse o que estava exposto já aparecia nos planos para o museu com a "montagem de exposições didáticas, periódicas, de História de São Paulo e do Brasil, e de Etnografia" 56, nas primeiras páginas do relatório de estreia do novo diretor. Percebemos o contato deste com as tendências contemporâneas apresentadas para a discussão da museologia e da museografia, assim como um bom diálogo com seus contemporâneos.

Neme tinha a preocupação constante em suas decisões de fazer a produção intelectual bem como o acervo do museu serem repassados de maneira inteligível ao público, em especial às escolas. Como ele não era um acadêmico de formação estrita, mas um intelectual que vinha de uma formação muito mais autônoma e com grande circulação no meio intelectual, talvez fosse mais fácil, devido a sua maleabilidade, imaginar o que as pessoas compreenderiam numa exposição e adequar sua linguagem para um aproveitamento mais dinâmico. 
57. Cf. Morin (1986)

58. Consideramos o ano de 1959 o início da tabela, por encerrar o mandato de Herbert Baldus como diretor em exercício e por ser o período de entrada de Paulo Duarte como diretor no museu, bem como para comparação de uma faixa de 10 anos de visitações com variações bastante sensíveis.
Embora Neme não fosse um intelectual em "torre de marfim", 57 ele os conhecia muito bem, e buscou tirar os intelectuais/funcionários do museu, distantes dos frequentadores do espaço, de suas salas, e intermediar pequenos contatos apresentando a produção acadêmica para uma gama ampla de público.

As visitas nunca cessaram e o número de escolares e demais visitantes cresceu vertiginosamente no decorrer do período estudado, como se observa no quadro 4.

Quadro 4. Número de visitantes ao Museu Paulista (1959 - 1971)

\begin{tabular}{|l|l|}
\hline \multicolumn{1}{|c|}{ Ano } & \multicolumn{1}{|c|}{ Número de visitantes no decorrer de um ano ao Museu Paulista } \\
\hline 1959 & 345.452 \\
\hline 1960 & 348.900 \\
\hline 1961 & 348.900 \\
\hline 1962 & 383.689 \\
\hline 1963 & 772.728 \\
\hline 1964 & 822.707 \\
\hline 1965 & 832.372 \\
\hline 1966 & 836.424 \\
\hline 1967 & 836.624 \\
\hline 1968 & 914.092 \\
\hline 1969 & 911.389 \\
\hline 1970 & 472.788 \\
\hline 1971 & 477.563 \\
\hline
\end{tabular}

Fonte: Dados retirados dos Relatórios de Atividades do Museu Paulista (1959 a 1971), não foram considerados os visitantes ao Museu Convenção de ltu. ${ }^{58}$

Crescimento no número de visitantes ocorreu por um conjunto de fatores: primeiro, o museu passou a abrir todos os dias com exceção das segundas-feiras, dia utilizado para atividades internas; segundo, um protocolo que foi progressivamente personalizado no atendimento às escolas; em terceiro lugar, muitas atividades da Faculdade de Ciências e Filosofia da Universidade de São Paulo passaram a acontecer nas dependências do museu. E, por fim, uma ampla divulgação dos trabalhos ali realizados em meios diversos, que contribuiu sobremaneira para a ampliação no número de visitantes. Os números descritos no quadro 4 são vultosos e nos colocam a questionar sua veracidade, contudo a busca pela confrontação com documentos oficiais não foi possível, uma vez que não os 
encontramos. Uma possibilidade é que estejam computados nestes números também os números aproximados de visitantes ao parque e não somente ao museu.

\section{MUSEU PAULISTA DA USP}

Entre as primeiras preocupações de Neme em seu mandato, ainda como diretor substituto, está a transferência do Museu Paulista enquanto órgão da Secretaria de Estado dos Negócios da Educação para Instituto da USP, proposta que já havia sido pensada anteriormente, mas que até aquele momento não fora efetivada.

Em 1963, após diversas solicitações e conversas, enfim o Museu Paulista é incorporado à Universidade de São Paulo. Para o museu, na figura do seu diretor, esse fato transformaria a realidade do espaço, mas talvez para a universidade isso não estivesse tão claro. Nas palavras de Ulpiano Bezerra Toledo de Meneses, "tal incorporação não obedecia a uma política consciente ou a uma percepção qualquer do papel que os museus pudessem desempenhar no universo acadêmico". 59 Enquanto para Neme

[...] a sua incorporação, como instituło anexo, a Universidade de São Paulo, propicia-se o melhor aproveitamento cultural do acervo histórico, artístico e arqueológico do Museu. Ao mesmo tempo, possibilita-se, através de regulamento a ser baixado pelo Reitor da Universidade, com a aprovação do Conselho Universitário, uma reestruturação orgânica mais racional e objetiva e uma administração mais harmoniosa, bem como o seu entrosamento com os demais órgãos da Universidade. .0

Assim, para o diretor estava claro que a incorporação do Museu Paulista pela USP significava a sua utilização enquanto espaço e acervo para o desenvolvimento científico por intermédio de aulas, pesquisas, ${ }^{61}$ debates. Na visão de Neme o museu era um espaço científico e enquanto tal deveria estar ligado à universidade para poder desenvolver suas funções de modo positivo e coerente. A gestão do museu, para seu diretor, significava por a coleção e o espaço do museu à disposição da comunidade acadêmica para pesquisa, e para a comunidade com a apresentação dos resultados dessas mesmas pesquisas.

Houve uma grande preocupação por parte de Neme de disponibilizar o espaço para as visitas escolares guiadas, pois o acervo por ele mesmo simplesmente disposto em salas não daria conta de revelar uma história, ou uma manifestação cultural de um dado lugar. A percepção museológica do autor era a moderna, em que há uma ideia a ser apresentada, na qual contexto e acervo necessitam dialogar para se ter
59. Meneses (1994, p. 573).

60. Neme (1963, p. 2.)

61. "Já havia atividade de pesquisa ao abrigo do $\mathrm{Mu}$ seu Paulista desde o fim do século XIX (Lopes, 1997), embora a criação de institutos estaduais de pesquisa, voltados especificamente ao estudo de determinados temas, tenha ocorrido ao longo das primeiras décadas do século XX (Santos, 2005). Até a década de 1950 , grande parte da pesquisa científica no estado de São Paulo foi desenvolvida nos institutos de pesquisa. O cenário no final dos anos 1960 e começo dos 1970 era, no entanto, de grande preocupação por parte dos cientistas dos institutos de pesquisa do Estado sobre o futuro dessas entidades. Num plano mais amplo, nessa época discutia-se a definição de Ciência e Tecnologia, pois havia a perspectiva de a Tecnologia tornar-se orientadora da Ciência, como parecia propor o projeto de lei $\mathrm{n}^{\circ} 205$ submetido à Assembleia Legislativa do Estado de São Paulo (Lane, 1974). O projeto propugnava pela extinção desses institutos e pela criação, em seu lugar, de três empresas de economia mista - medida de iniciativa do então governador Laudo Natel, que não foi aprovada. A minuta já havia sido rejeitada frontalmente pelos cientistas, que optavam pela implantação efetiva da carreira de pesquisador científico e o credenciamento dos institutos de pesquisa do Estado como centros complementares da Universidade no ensino de pós-graduação. Efetivamente, a criação da carreira de Pesquisador Científico nos institutos de pesquisa das Secretarias do Estado de São Paulo foi implantada por meio da Lei Complementar $\mathrm{n}^{\circ} 125$, de 18 de novembro de 1975 .” ( Brandão; Costa 2007). 
62. Cf. Elias (2011).

63. O conceito campo, utilizado neste trabalho é o criado por Pierre Bourdieu (2004, p. 20), que o define como: "para compreender uma produção cultural (literatura, ciência etc.) não basta referir-se ao conteúdo textual dessa produção, tampouco referir-se ao contexto social contentando-se em estabelecer uma relação direta entre texto e o contexto [...] Minha hipótese consiste em supor que, entre esses dois polos, muito distanciados, entre os quais se supõe, um pouco imprudentemente, que a ligação possa se fazer, existe um universo intermediário que chamo o campo literário, artístico, jurídico ou científico, isto é, o universo no qual estão inseridos os agentes $\mathrm{e}$ as instituições que produzem, reproduzem ou difundem a arte, a literatura ou a ciência. Esse universo é um mundo social como os outros, mas que obedece a leis sociais mais ou menos específicas".

64. Ibid., p. 24

65. Ibid., p. 24 uma apreensão do papel do museu. Neme busca romper com a museologia da simples apresentação de peças, para uma apresentação crítica destas.

Muitas mudanças realizadas pelo diretor foram possíveis devido a sua presença constante no museu. Ele ia todos os dias ao museu, para despachar e estudar. ${ }^{62}$ Participava ativamente do cotidiano do espaço. Este fato propiciou um contato intenso com as necessidades urgentes do museu. A constância do gestor e seu campo ${ }^{63}$ de relações fez com que suas intervenções agissem de maneira pontual para fazer alterações gerais no espaço.

A retomada da publicação dos Anais do Museu Paulista foi essencial, enquanto estrutura para um campo intelectual como descreve Sirinelli, pois com ele Mário Neme pode não somente oferecer um espaço de publicação, mas também demonstrar seu poder de atuação e de relações estabelecidas, contribuindo para a notoriedade dos Anais, agora com um número expressivo de contribuições de professores da Universidade de São Paulo. É importante salientar que, nesse momento, as gerações formadas por esta instituição desejavam fixar-se e estavam tentando minimizar a presença dos intelectuais polígrafos como Mário Neme.

Esses jovens intelectuais formados pela USP iriam consolidar-se e atuar em parte nesta mesma instituição, em jornais, em editoras, etc. Assim, gradativamente o diploma universitário passou a ser pré-condição para o estabelecimento de uma nova intelectualidade. Um bom exemplo disso pode ser observado no $\bigcirc$ Estado de S. Paulo de 9 de setembro de 1956, quando o jornal anuncia seu novo suplemento cultural, concebido por Antonio Candido. Candido chama nomes de vanguarda para atuar no suplemento, pondo a cultura universitária em destaque. Entre os presentes na lista de colaboradores estavam Décio de Almeida Prado e Paulo Emilio Salles Gomes, ambos estudantes e futuros professores da USP.

Pierre Bourdieu (2004) nos ajuda a compreender estas tensões, pois "os agentes (indivíduos ou instituições) caracterizados pelo volume de seu capital determinam a estrutura do campo em proporção ao seu peso, que depende do peso de todos os outros agentes, isto é, de todo o espaço". Por outro lado, "cada agente age sob a pressão da estrutura do espaço que se impõe a ele tanto mais brutalmente quanto seu peso relativo seja mais frágil". ${ }^{64}$ Assim, possuir a Universidade de São Paulo ao lado em um empreendimento, em especial, aqueles ligados à intelectualidade, era adentrar num campo de distinção, entre os demais segmentos e agentes, e passar a ser parte desse "campo distinto em formação". 65 
Quando Mário Neme assume a direção do Museu Paulista, os Anais do Museu Paulista haviam deixado de ser impressos em favor da publicação da Revista do Museu Paulista, segundo os relatórios de atividade da época, devido à ausência de verbas para ambos. Neme conhecia os Anais e sabia de sua repercussão e importância como instrumento de divulgação das pesquisas realizadas no museu. Logo que assume sua função, passa a solicitar verba para a retomada da publicação dos Anais.

Mário Neme defende, em seu primeiro relatório de atividades em 1960, o quão importante são os Anais do Museu Paulista para a cultura de São Paulo, e o risco que se corre com a sua não publicação. $\bigcirc$ pedido de verba para a volta da tiragem periódica dos anais é realizado com muita diplomacia, apontando para o secretário a pujança do estado que não poderia deixar de possibilitar a circulação de uma publicação muito bem-conceituada.

Caracterizando-se a presente administração do Estado pelo incremento de todas as atividades de caráter científico e cultural, fundamento de todo progresso técnico, industrial, agrícola e comercial de São Paulo, é natural que os "Anais do Museu Paulista" voltem a circular com a regularidade que fez deles a publicação prestigiosa e autorizada de outros tempos.

$[\ldots]$

Além do desprestígio que esse fato acarreta diretamente para o Museu Paulista, indiretamente para a Secretaria da Educação e para o Governo do Estado, há a considerar um inconveniente dificilmente reparável que daí decorre. Numerosas instituições de todos os Estados do Brasil, e muitas do Exterior, em vista de não continuarem recebendo os "Anais" do Museu, deixaram de nos remeter as suas publicações seriadas, causando com isso faIhas nas coleções, falhas que só em lances de muita sorte serão em pequena parte preenchidas [...] $\bigcirc$ prejuízo que o Museu Paulista está tendo em virtude desse estado de coisas é impossível de calcular, mormente quando se sabe que a permuta de publicações é que constitui a principal forma de correspondência entre os pesquisadores e o mais positivo fator de progresso dos estudos especializados. ${ }^{60}$

intelectual ataca por duas frentes diferentes para conseguir o financiamento para as publicações do Museu Paulista, por um lado sempre demonstrando o potencial de São Paulo e tudo que o Estado já fez pela instituição, por outro, mostrando a produção intelectual do museu como obra de reconhecido valor e com conhecimento de toda a gestão do museu. Após o envio do relatório citado acima, os Anais passaram a ter edições constantes. 
67. Neme (1969a, p. 1).

68. Em 13 de dezembro de 1968, o Ato Institucional $n$. 5 passou a vigorar, e entre seus artigos estava o $n^{\circ} 6$, que decreta: "Ficam suspensas as garantias constitucionais ou legais de: vitaliciedade, inamovibilidade $\mathrm{e}$ estabilidade, bem como a de exercício em funções por prazo certo." Em seu primeiro inciso lemos a invasão do artigo na esfera pública: "O Presidente da República poderá mediante decreto, demitir, remover, aposentar ou pôr em disponibilidade quaisquer titulares das garantias referidas neste artigo, assim como empregado de autarquias, empresas públicas ou sociedades de economia mista, e demitir, transferir para a reserva ou reformar militares ou membros das polícias militares, assegurados, quando for o caso, os vencimentos e vantagens proporcionais ao tempo de serviço." Brasil (1968). O AI-5 como ficou mais comumente conhecido foi uma artimanha atroz do governo militar contra a população brasileira, e assim também contra os serviços públicos.

69. Neme (1969b, p. 1).

70. Associação de Docentes da USP (2004, p. 46-49).

71. Ibid., p. 46-49.

72. Ibid., p. 73 .

\section{O GOLPE CIVIL-MILITAR E OS MUSEUS}

Após o golpe civil-militar, as mudanças sofridas pela universidade são visíveis, e infelizmente os museus não ficaram imunes. Em etapas, o corte de verbas junto aos institutos da USP foi se agravando, e, assim, pouco a pouco, o governo militar atacou a universidade e tirou os investimentos em pesquisa e extensão.

Em 1968, Neme registra as dificuldades enfrentadas pelo museu, anunciando: "devemos esclarecer que as atividades do Museu Paulista foram muito prejudicadas por carência de recursos financeiros e de pessoal, tanto técnicocientífico como burocrático". ${ }^{67}$ A crescente busca pelo acervo do museu era notória, e sua necessidade de crescimento em termos de pessoal também. Obviamente, é notória a queda nas atividades do museu, sobretudo após 1968, quando foi instituído o Al-5.68 Em relatório de 1969, o diretor expõe as implicações dos cortes para o planejamento das atividades do museu:

Esses cortes foram de tal profundidade, que tornaram inúteis os cálculos, mensuração, planos e objetivações a que se procedeu e que se tinha em vista, de tal forma que todo e qualquer planejamento que se podia pretender ficou de antemão anulado. $\bigcirc$ principal entrave causado por esses pré-cortes - depois de apuradas com a maior ponderação as necessidades mais prementes do Instituto - refere-se ao capítulo do pessoal, trazendo em consequência a impossibilidade de atender às exigências mínimas do serviço. Nesse fato, que foge a qualquer previsão, além de quebra de rendimento, provoca, como é natural, protestos e até revolta nos Chefes de Secções e responsáveis por serviços e setores. ${ }^{69}$

Dessa maneira, o museu sofria com problemas gerados pelas mudanças políticas impostas. Com a aposentadoria compulsória de diversos professores da Faculdade de Filosofia, Ciências e Letras, como Emília Viotti da Costa, Otávio lanni, Paula Beiguelman, Mário Schenberg, ${ }^{70}$ entre tantos outros, a USP adentrou num difícil processo de adaptação e convivência com as perdas significativas que ocorreram e com a perseguição política em todos os níveis, que visava desde alunos e professores até funcionários..$^{71} \mathrm{Em} 1978$, quando prestou seu depoimento sobre o funcionamento da USP durante o regime ditatorial, o ex-reitor Antônio Guimarães Ferri explicou a existência junto ao Ministério da Educação de um Serviço de Segurança do Ministério, a quem sempre precisava se reportar, bem como este órgão possuía um funcionário atuando dentro da reitoria. Perguntado se haveria uma comissão desse ministério dentro da universidade, ele declarou: "há uma pessoa na Universidade que naturalmente leva as indicações ou os processos para a comissão de fora da Universidade..."72 Assim, a contratação de professores e pesquisadores deixou de ser uma decisão autônoma da universidade para 
depender de uma análise externa determinada por um obscuro e confuso julgo de uma comissão de segurança. ${ }^{73}$ A universidade "se via agredida, de fora, pelo governo militar da época e, internamente, pelos que o apoiavam". ${ }^{74}$

Para Mário Neme, enquanto diretor do Museu Paulista, a diferença na realidade diária da instituição foi substancial, com a queda de verbas e a saída de muitos pesquisadores da universidade que utilizavam o museu como espaço de pesquisa, sobretudo utilizando seu acervo. Em entrevista, a professora Emília Viotti da Costa $^{75}$ relembrou a atenção dada por Neme aos pesquisadores que utilizavam o acervo do museu, orientando muitas vezes quanto aos documentos e incentivando os pesquisadores, oferecendo auxílio nas investigações. Fato que demonstra sua grande familiaridade com o acervo, fruto de muitas pesquisas e interesse pelo museu. As perseguições e insegurança geradas pela presença dos militares na universidade fizeram com que muitos desses pesquisadores se tornassem menos frequentes no museu, e muitas parcerias firmadas pelo uso da Faculdade de Filosofia, Ciências e Letras terminassem de forma abrupta com a aposentadoria compulsória de muitos professores.

\section{CONSIDERAÇÕES FINAIS}

A atuação de Mário Neme na direção do Museu Paulista viabilizou ações para o desenvolvimento e uso efetivo do Museu Paulista pelo público, fosse ele escolar, visitante eventual, pesquisador ou professor.

golpe civil-militar, e a consecutiva perda de importantes professores que poderiam continuar colaborando para a inserção do Museu Paulista no meio universitário, fragilizou enormemente o trabalho que Mário Neme vinha desenvolvendo há uma década, e que culminou com a mudança do museu da Secretaria de Educação do estado para um museu universitário.

Com o regime militar, o intelectual foi pouco a pouco paralisado. A presença militar no governo foi imensamente danosa não só para a vida política da USP, mas também para os serviços administrativos, com cortes de verbas e perseguições a docentes e funcionários. Como diretor de uma instituição da universidade, Mário Neme sentiu em suas ações cotidianas o peso dos fatos ocorridos, tanto que a perda de qualidade na diversidade de informações apresentadas nos relatórios dos anos finais de seu mandato é significativa.

Nesse sentido, a ausência de referências detalhadas de nomes e atividades desenvolvidas nas dependências do museu difere muito dos relatórios anteriores. Além
73. Sobre o período da ditadura militar e suas implicações na USP, cf. Oliveira; Candido; Silva (1995); Associação de Docentes da USP (2004).

74. Oliveira; Candido; Silva (1995, p. 09).

75. Cf. Costa (2014) 
da doença que o atormentava em seus últimos anos de vida, teve de lidar também com a saída de forma arbitrária de diversos colegas de trabalho da universidade, agindo com atenção redobrada para não expor o museu a situações de risco.

Por fim, as informações comentadas anteriormente têm sua origem a partir de relatórios de atividades do Museu Paulista, em suas versões de rascunho ou cópia à carbono, alguns com mais de uma versão. Esse é um fato relevante, pois comumente existia uma versão do relatório de atividades final arquivado no museu. Muitos documentos acerca da gestão de Neme, como materiais de seminários oferecidos por professores, anotações pessoais e cartas são raríssimos, fato muito curioso quando falamos de um homem que era jornalista, historiador, pesquisador e possuía uma ampla rede de sociabilidade. 


\section{REFERÊNCIAS}

FONTES IMPRESSAS

Documentação oficial do museu paulista

BALDUS, Herbert (dir.). Relatório de atividades do Museu Paulista no decorrer do ano de 1954. São Paulo: Mimeo, 14 jan. 1955.

BALDUS, Herbert (dir.). Relatório de atividades do Museu Paulista no decorrer do ano de 1956 a 1959. São Paulo: Mimeo, 14 jan. 1960a.

BALDUS, Herbert. Relatório de atividades do Museu Paulista no decorrer do ano de 1959. São Paulo: Mimeo, 15 jan. 1960b.

HOLANDA, Sérgio Buarque de (dir.). Relatório de atividades do Museu Paulista no decorrer do ano de 1955. São Paulo: Mimeo, 1956.

LEITE, Francisco Rodrigues Leite. Relatório da secção de História do Museu Paulista. São Paulo: Mimeo, 1960.

NEME, Mário (dir.). Relatório de atividades do Museu Paulista no decorrer do ano de 1960[1]. São Paulo: Mimeo, 15 jan. 1961[2]. Encadernado, nº. L43.

NEME, Mário (dir.). Relatório de atividades do Museu Paulista no decorrer do ano de 1962. São Paulo: Mimeo, 15 jan. 1963.

NEME, Mário (dir.). Relatório sucinto das atividades do Museu Paulista no decorrer do ano de 1964. São Paulo: Mimeo, 14 dez. 1964.

NEME, Mário (dir.). Relatório sucinto das atividades do Museu Paulista no decorrer do ano de 1965. São Paulo: Mimeo, 4 jan. 1966.

NEME, Mário (dir.). Relatório sucinto das atividades do Museu Paulista no decorrer do ano de 1966. São Paulo: Mimeo, 6 mar. 1967. 
NEME, Mário (dir.). Relatório sucinto das atividades do Museu Paulista no decorrer do ano de 1967. São Paulo: Mimeo, 12 mar. 1968.

NEME, Mário (dir.). Relatório sucinto das atividades do Museu Paulista no decorrer do ano de 1968. São Paulo: Mimeo, 9 jan. 1969a.

NEME, Mário (dir.). Relatório sucinto das atividades do Museu Paulista no decorrer do ano de 1969. São Paulo: Mimeo, 31 dez. 1969b.

NEME, Mário (dir.). Relatório sucinto das atividades do Museu Paulista no decorrer do ano de 1970. São Paulo: Mimeo, 9 fev. 1971a.

NEME, Mário (dir.). Relatório sucinto das atividades do Museu Paulista no decorrer do ano de 1971. São Paulo: Mimeo, 17 dez. 1971b.

NEME, Mário (dir.). Relatório sucinto das atividades do Museu Paulista no decorrer do ano de 1972. São Paulo: Mimeo, 4 jan. 1973.

Outros documentos oficiais

BRASIL. Ato Institucional No 5, 13 dez. 1968.

DECRETO n. 21.129, 7 mar. 1932, cria o Curso de Museus no MHN. Disponível em: <https://bit.ly/3acO9HI>. Acesso em: 2 fev. 2014.

REGULAMENTO do Museu Paulista, art. $2^{\circ}, 1894: 4$.

Períodicos

LUCCA Jr., Domingos. Plano para 2 museus, sonho de 1 homem só. Folha de S.Paulo, São Paulo, 4 jul. 1962.

NEME, Mário. Utilização cultural de material de museu. In: Anais do Museu Paulista, Tomo XVIII, São Paulo, 1964b, p. 7-62.

LIVROS, ARTIGOS E TESES

ALVES, Ana Maria de Alencar. O Ipiranga apropriado. Ciência, política e poder. O Museu Paulista 1893-1922. São Paulo: Humanitas, 2001. (Série Teses).

ASSOCIAÇÃO de Docentes da USP. O controle ideológico na USP: 1964-1978. São Paulo: ADUSP, 2004. 
ARRUDA, Maria Arminda do Nascimento. Metrópole e Cultura. São Paulo no meio do século XX. Bauru, SP: Edusc, 2001.

BARBUY, Heloísa. O Campus do Ipiranga. In: Cidades Universitárias: Patrimônio urbanístico e arquitetônico da USP. São Paulo: Edusp: Imprensa Oficial, 2005.

BOURDIEU, Pierre. Os usos sociais da ciência. Por uma sociologia clínica do campo cientifico. Trad. D. B. Catani. São Paulo: Unesp, 2004.

BOURDIEU, Pierre. As regras da arte: gênese e estrutura do campo literário. $2^{\mathrm{a}}$ ed. $1^{\mathrm{a}}$ reimp. Trad. M. L. Machado. São Paulo: Companhia das Letras, 2010.

BRAGA, Ana Isabel Vieira. Sistemas de documentação e inventário de uma colecção de cerâmica arqueológica da Quinta do Rouxinol. Relatório Mestrado (Museologia) - Faculdade de Ciências Sociais e Humanas, Universidade Nova de Lisboa, Lisboa, 2010.

BRANDÃO, Carlos Roberto Ferreira; COSTA, Cleide. Uma crônica da integração dos museus estatutários à USP. Anais do Museu Paulista, v. 15 n. 1 São Paulo jan./jun. 2007.

BREFE, Ana Cláudia Fonseca. O Museu Paulista. Affonso de Taunay e a memória nacional. São Paulo: Unesp: Museu Paulista, 2005.

CANDIDO, Antonio. Literatura e sociedade; estudos de história literária. 10 a ed. Rio de Janeiro: Ouro sobre Azul, 2008.

COSTA, Madalena Cardoso da. João Rodrigues da Silva Couto e a "inovação museológica" em Portugal no século XX (1938-1964). In: ASENSIO, Mikel; LIRA, Sérgio; ASENJO, Elena; CASTRO, Yone. (eds). SIAM. Historia de las Coleciones, Historia de los Museos. Ano 3, v. 6, Universidad Autónoma de Madrid, 2012, p. 55-63.

CHOAY, Françoise. A alegoria do patrimônio. Lisboa: Edições 70, 2000.

COUTO, João. Curso de Museologia a estagiários para conservadores dos Museus, Palácios e Monumentos Nacionais. Separata de: Revista Ocidente, Lisboa, p. 1-23, 1965.

DUARTE, Paulo. Memórias. Selva obscura. v. III São Paulo: Hucitec, 1976.

ELIAS, Maria José. A morte de um liberal: uma louvação tardia. In: Anais do Museu Paulista, Tomo XXVIII, São Paulo, 1977/1978, USP, p. 101-117. 
FARIA, Ana Carolina Gelmini de. Educar no museu: o Museu Histórico Nacional e a educação no campo dos museus 91932-1958). 2017. 292 f. Tese (Doutorado em Educação) - Faculdade de Educação, Universidade Federal do Rio Grande do Sul, Porto Alegre, 2017.

FERNÁNDEZ, Luis Alonso. Museología. Introducción a la teoría y práctica del museo. Madri: Istmo, 1993.

FLEMING, Maria Isabel D’Agostinho; FLORENZANO, Maria Beatriz Borba. Trajetória e perspectivas do Museu de Arqueologia da USP (1964-2011). Estudos Avançados, São Paulo, v. 25 n. 73, p. 217-228, 2011.

FRANÇOSO, Mariana. O Museu Paulista e a história da antropologia no Brasil entre 1946 e 1956. Revista de Antropologia, São Paulo, v. 48, n. 2, p. 585-612, 2005.

HAYASHI, Maria Guimarães. Paulo Duarte, um Dom Quixote brasileiro. 2001. 200 f. Tese (Doutorado em História) - Faculdade de Filosofia, Letras e Ciências Humanas, Universidade de São Paulo, São Paulo, 2001.

HOLANDA, Sérgio Buarque de. Entrevista com Sérgio Buarque de Holanda (1981). Novos Estudos, São Paulo, n. 69, p. 3-14, jul. 2004.

LOPES, Maria Margaret. O Brasil descobre a pesquisa científica. Os museus e as ciências naturais no século XIX. 2 ed. São Paulo: Hucitec; Brasília: UnB, 2009.

LOUSADA, Ana Maria. Conservador e Museólogo: Abordagem de Conceitos. Cadernos de Museologia, n. 1, 1993.

MAGALHÃES, Aline Montenegro. Troféus da guerra perdida: um estudo histórico sobre a escrita de si de Gustavo Barroso. 2009. Tese (Doutorado em História Social) - Universidade Federal do Rio de Janeiro, Rio de Janeiro, 2009.

MALHEIRO, Maria Cecília Stávale. O arquivo Aguirra do Museu Paulista. In: Anais do Museu Paulista, t. 28, 1977/1978.

MENESES, Ulpiano Toledo Bezerra de. Museu Paulista. In: Estudos Avançados, São Paulo, v. 8, n. 22, 1994, p. 573-578.

MENDONÇA, Edgar Sussekind de. A extensão cultural nos museus. Rio de Janeiro: Museu Nacional, 1946. (Publicações avulsas, 3). 
MISAN, Simona. Os museus históricos e pedagógicos do estado de São Paulo. Anais do Museu Paulista, São Paulo, v.16. n.2. p. 175-204. jul.-dez 2008.

MORIN, Edgar. Para sair do século XX. 30ª ed. Rio de Janeiro: Nova Fronteira, 1986.

PAULA, Eurípedes Simões de. Prefácio. Dédalo, São Paulo, v. 1, p. 02, 1965.

PFROMM NETO, Samuel. O gigante piracicabano: Mário Neme. In: Piracicaba de outros tempos. Campinas/SP: Ed. Átomo, Ed. PNA, 2001, p. 67-73.

REVISTA DO BRASIL. Número especial dedicado a Sérgio Buarque de Holanda. Rio de Janeiro, Rio Arte, ano 3, n. 6/87, jul. 1987.

SIRINELLI, Jean-François. F. Os intelectuais. In: REMOND, René. (org.). Por uma história política. $2^{\text {a }}$ ed. Trad. D. Rocha. Rio de Janeiro: FGV, 2003, p. 231-260.

SEVCENKO, Nicolau. Literatura como missão. Tensões sociais e criação cultural na primeira República. São Paulo: Companhia das Letras, 2009.

SCHWARCZ, Lilia Moritz. O espetáculo das raças. Cientistas, instituições e questão racial no Brasil (1870-1930). 10ª reimp. São Paulo: Companhia das Letras, 2011.

SILVA, Tathianni Cristini da. O texto, ações intelectuais e o desenvolvimento do pensamento museológico nas décadas de 1950 a 1970. In: CHRISTOFOLETTI, Rodrigo (org.). Bens culturais e Relações internacionais. O patrimônio como espelho do soft power. Santos: Editora Universitária Leopoldianum, 2017, p. 301-318.

SIQUEIRA, Graciele Karine. Curso de Museus - MHN, 1932-1978. O perfil acadêmico profissional. 2009. 178 f. Dissertação (Mestrado em Museologia e Patrimônio) - Centro de Ciências Humanas e Sociais, Universidade Federal do Estado do Rio de Janeiro, Rio de Janeiro, 2009.

VALENTE, Giselle Laguardia. As missões culturais de Sérgio Buarque de Holanda. 2009. 319 f. Tese (Doutorado em Memória Social) - Centro de Ciências Humanas e Sociais, Universidade Federal do Estado do Rio de Janeiro, Rio de Janeiro, 2009.

\section{Entrevistas}

COSTA, Emília Viotti da. [Entrevista cedida a] SILVA, Tathianni Cristini da. São Paulo, 22 fev. 2014.

ELIAS, Maria José. [Entrevista cedida a] SILVA, Tathianni Cristini da. São Paulo, 26 out. 2011. 
Artigo apresentado em 24/06/2019. Aprovado em 16/12/2019.

\section{(cc) BY}

All the contents of this journal, except where otherwise noted, is licensed under a Creative Commons Attribution License 